\title{
Pedagogical-culture Implementation in English Classroom of Islamic Boarding School
}

\author{
A H As Sabiq ${ }^{1}$, Y Purnama ${ }^{2}$ D Mulyadi ${ }^{3}$ \\ ${ }^{1,2}$ Department of English Education, IAIN Purwokerto, Purwokerto \\ ${ }^{3}$ Department of English Education, Universitas Muhammadiyah Semarang, Semarang \\ E-mail: husein@iainpurwokerto.ac.id
}

\begin{abstract}
Understanding the nature of the relationship between language and culture is central to the process of learning another language. Multicultural backgrounds of the students and the culture of the boarding school environment in MTs Al Iman Purworejo become the challenge for the teacher in delivering the course especially in ELT. The objectives of this research are: (1) to describe the implementation of Islamic boarding school (Pesantren) culture in ELT in MTs Al Iman Purworejo; (2) to find out its effects in English learning. This research used ethnography approach with qualitative data. The data sources in this research were teacher, students that were 2 classes from class VII and 2 classes from class VIII, and all written materials either in the form of books, reports, documents relating to research. There were some findings that can be concluded from this research, those are: (1) The teacher developed the learning materials by himself in accordance with the context and culture of Al Iman environment; (2) the teacher was open minded and flexible to receive the technological changes as the culture in Al Iman boarding school; (3) Interactive learning was implemented by the teacher in which he has a good relationship with the students.
\end{abstract}

Keywords: Pedagogical, Culture, Pesantren, English

\section{INTRODUCTION}

Understanding learners' background is a must to avoid misunderstanding of students' abilities and to teach English effectively, especially in a multi-cultural classroom [1]. Learning is a social process in which culturally and historically situated participants engage in culturallyvalued activities, using cultural tools. Based on the history, pesantren becomes a cultural heritage of Islam in Indonesia. It is not only an educational institution, but the culture of Islam itself. Education does not become a didactic process an sich, but the mode of being release from Islam [2]. 
Pesantren, either from the root or tradition that is formed in it, basically it is indigenous. The word "Pesantren" itself comes from the Sanskrit word or Pali, "shastri", a term to see the scholar possesses the expertise of scriptures, reveals the roots the word "santri" comes from the word "cantrik". Steenbrink argues that pesantren is not originated from the Arabic term, but from India [3]. Pesantren, viewed in terms of form and the system, originated in India. Before the process of spreading Islam in Indonesia, the system has been used on a regular basis common for Hindu religious teachings at Java. Pesantren culturally is an educational institution born of Indonesian culture, and historically contained not only the meaning of Islam, but also the meaning of Indonesian. This can not be separated anyway from a new paradigm promoted by Manger cited by Wahid [4] who sees religion as not a black-and-white matter, not a single matter, belongs to the Middle East, but Islam has made a dynamic dialectic between Islam in the universal category with the locality in which it lives.

There are some of the cultures applied in pesantren. First is the spirit of learning. According to Haedari [5], pesantren has taught the classical books of Islam, Arabic-speaking and unanimous. In this case, santri is taught from the basis of Nahwu Sharaf to be able to read with deep meaning of the Islamic books. The second is ethics or moral values. Morals are the core learning that pesantren applies to the students. As explained by Rofik [6], the purpose of pesantren is tafaqquh fiddin (understanding religion) and forming morality of people. The last is social character. Rofik added, pesantren is an integral unity that cannot be separated from objective reality of society to be able to answer the challenges of this era [6]. So no wonder if in pesantren, education also leads to the formation of social characters such as helpful, harmonious and peaceable, full of responsibility for the good of people, and so on.

The link between foreign language learning and culture learning has been established by the linguists and anthropologists a long time ago [7] [8]. In seeing the relationship between language and culture, Kramsch, cited in Risager [9] sees language in its function to express, display, and symbolize cultural reality.

There are several practical ways to effectively teach culture, along with teaching a language. Those are providing students with authentic materials, comparing and contrasting proverbs, using role plays, researching cultural items, and students as cultural resources [10]. Teachers as learning agents have the roles such as facilitators, motivators, drivers, learning engineers, and learning inspiration for students. Teacher competency as referred to in Article 8 of the Law of the Republic of Indonesia number 14 of 2005 includes pedagogic competence that is the ability of teachers in managing learning, at least covering (1) understanding of insight or foundation of education, (2) understanding of students, (3) developing curriculum / syllabus, (4) designing learning, (5) implementation educative and dialogical learning, (6) utilization of learning technology, (7) evaluation of learning processes and results, and (8) development of students to actualize their various potentials.

The goal of teaching is student learning. Much recent attention has been on this issue like in Indonesia that implemented curriculum 2013. On the other hand, MTs Al Iman is an Islamic junior high school that has its own characteristics. One of the differences of MTs Al Iman Purworejo from other MTs or junior high schools is in terms of curriculum. MTs Al Iman has a curriculum that combines national education curriculum and its own curriculum, plus extracurricular activities in schools. The students of MTs Al Iman also live in dormitories provided by the boarding school. Students also must comply with all existing regulations, not only rules of school but also rules of boarding school. Male and female students live in separated dormitories, but each dormitory has rules and activities that are almost the same as had been 
arranged by the foundation of the boarding school. Dormitory has right to make their own policy, but still with the approval of the boarding school foundation. In designing learning process, developing materials and boarding school environment, the cultural context should be considered. The teacher should realize the various backgrounds of the students and also the culture where they live. Thus, in MTs Al Iman Purworejo where the majority of the students live in boarding school, the teacher is demanded to design teaching and learning process correlated with the cultural environment of the students. The culture of boarding school should be included in the class due to the purpose of learning is appropriate with the purpose of boarding school.

Multi-cultural backgrounds of the students and the culture of the boarding school environment in MTs Al Iman Purworejo become the challenge for the teacher in delivering the course especially in English classroom. The strategies and the materials that the teacher used should be appropriate with students' culture. How the teacher deals with these various backgrounds becomes the point of this research.

From the background of the study above, the writer limits the problems that are going to be discussed. This research focuses on how the implementation Islamic boarding school (Pesantren) culture in teaching and learning process in MTs Al Iman Purworejo and also how the implementation can affect English learning. The objectives of this research are: (1) To describe the implementation of Islamic boarding school (Pesantren) culture in teaching and learning process in MTs Al Iman Purworejo; (2) To find out the effects of the implementation in English learning in MTs Al Iman Purworejo.

\section{METHOD}

This research uses ethnography approach as in Hammersley[11]. Related to this matter, hence this research aims to explore the form of pesantren culture which is implemented in English learning process in MTs Al Iman Purworejo and also its influence in learning process.

Primary data source in this research is teacher and student of MTs Al Iman Purworejo. There are more than 1000 students in MTs Al Iman Puworejo. Therefore, in determining the data sources, the researcher took four classes as the research sample, 2 classes from class VII and 2 classes from class VIII. While the secondary data sources in this study are all written materials either in the form of books, reports, documents relating to research.

This research used some techniques and instruments. They were: (1) participatory observation, the instruments of participant observation were the form of observation sheet and field notes which are used to record what happen in the classroom and the environment in Pesantren. (2) Interview is used to find out the information of the preparation and implementation of pesantren culture by the teacher. (3) Documentation, the document as a source of data to be used in this research is the official and personal documents owned by the pesantren, MTs Al Iman Purworejo, and teachers.

Referring to the data analysis techniques, data analysis that will be conducted on this research as in Bogdan \& Biklen [12] are; First, the domain analysis is to obtain a general and comprehensive picture of the object of research or social situation under study. Second, the taxonomic analysis which describes the selected domains to be more detailed, to know the internal structure. Third, the component analysis is an analysis that seeks the specific characteristics of each internal structure by contrasting elements. The analysis will be done as a 
selected observation and interview with contrast question (Contras Question). Fourth, the analysis of cultural themes is to find relationships between domains, and how relationships with the whole.

\section{RESULT and DISCUSSION}

Al Iman Islamic Boarding School has several characteristics that become its trademark and triggers the development of Islamic boarding schools. Among others are:

\subsection{Flexibility and open minded}

The management of Al Iman Islamic Boarding School is open minded to receive globalization changes. Pesantren facilities and infrastructure are equipped with information and technological equipment. Sometimes, pesantren teachers teach the students using technological tools, not always use classical systems. Easy to accept technological developments, Al Iman Boarding Schools tried not to miss renewable information.

\subsection{Group discussion}

Discussion activities in small groups or in large groups become the characteristic of $\mathrm{Al}$ Iman boarding students. They are accustomed to discuss in solving the problems. After completing the Maghreb prayer, the students will go to their respective classes according to their level to attend religious scientific development activities. MTs (junior high school) students are required to recite the Qur'an with one of the seniors as the facilitator in a small group consist of 5-6 students. Small group discussion such as this makes the learning process more conducive and directed. While $M A$ (senior high school) students carry out whole class discussion activities related to fiqh or Arabic grammar. In this discussion activity, there was one group that gave a presentation in front of the class and the audience asked questions or objections, so that the atmosphere of the class was interesting scientific debate.

In addition to activities after the Maghreb prayer, the students in every 9 pm carry out joint learning activities which are sometimes accompanied by one of the seniors. The difference with activities after Maghreb, this joint learning activity focused more on learning the lessons they will learn in school in the next day. In this activity, the students also gather in small groups. Students who have high intelligence often become peer tutors for others. This activity greatly supports the level of understanding of students in the school so that it is easy to receive further lessons.

\subsection{Good interaction between the senior and junior}

Most of the teachers in Al Iman were the senior santri (student) or alumni. They have been recognized better the characteristic of the students.

\subsection{Character building and soft skill}

Beside the improvement of religious knowledge, the activities of students in Al Iman boarding school are also aimed to improve students' characteristics and soft skill. For example, every Saturday night there is a public speaking activity which its purpose is to maintain students' 
talents and potentials skill. Sometimes, the students used bilingual speech (Bahasa Indonesia and English or Arabic) in discussion. Also, every Thursday night the students did activity called simtud-duroran that is reading the biography of Prophet Muhammad PBUH.

\subsection{Respect to the older}

Another culture that the students usually do in their lives is respecting the older (senior / administrator / kyai (cleric)). It is proved by their speech when making interaction with the older students. They will use boso kromo that is the highest level of Javanese language.

Some important points in pedagogical-culture implementation in English Classroom of Islamic Boarding School can be found as follows:

\subsection{Flexibility and open minded}

The teacher used the technological media in delivering the explanation. He is open minded to receive the renewable technological information in ELT. The teacher used audio-visual media in teaching and learning process. The implementation of the audio-visual media as alternative media used in English class had two benefits. First, the use of audio-visual media was effective in promoting students' motivation in learning English. They felt that they were not bored or sleepy anymore during the learning activities. They were challenged to observe, analyze, and communicate their ideas. Second, according to the teacher, the students seem to be more active in the class. When they were asked to be volunteer, they scrambled to the first student who was pointed by the teacher to do the task in front of the class. The students were asked about the media used by the teacher. They had positive attitudes towards the media and the enjoyed it. Students' feelings in engaging the learning process showed that the students had positive attitudes. They said:

Researcher: Do you like the instructional media used by your teachers?

Student: Yes I do. Teacher uses pictures or play a video in explaining the lesson.

Researcher: What is/are your favorite activity/ies in English lesson?

Student: I like singing..

\subsection{Problem based learning}

The teacher also used the problem based leaning. This method is basically implemented in the students' daily activities when they do group discussion after Maghreb pray and joint learning after 'isya prayer. Group discussion became the students' habit in their dormitory, so the teacher took this strategy in enhancing the learning process in the class. When the teacher was asked about the influence of students learning habit in their dormitory, he explained that the group discussion is a routine activity in the dormitory.

\subsection{Contextualized material and character building}

The teacher arranged the learning materials by himself in accordance with the context of the environment. The picture, for example, is contextualized with the pesantren culture and environment. The teacher delivered the materials in integration with the pesantren context. Also, the important point was inserting moral values in the material. 


\subsection{Public speaking}

In every group discussion, the students were asked to communicate the result of the discussion in front of the class. Oral presentation practice was used by the teacher to improve the students' speaking skill. Beside improving students' speaking skill, the purpose of this activity was also to build students' characters as the activity that is usually followed in every Saturday night, i.e. khitobah (public speech).

\subsection{Good relationship}

The atmosphere in the class is in conducive matter because the teacher could manage the class properly. This is because a good relationship between the teacher and the students where they will always meet each other not only in the classroom, but also in the dormitory and pesantren activities. The tasks that the teacher gave are always done by the students.

\section{CONCLUSION}

Teacher could understand the students' characteristics. This was basically very normal because the teacher was also the senior santri (student) there. The teacher could develop the learning materials in accordance with the context of Al Iman environment. The teacher delivered the materials in integration with the pesantren context. The important point was inserting moral values in the material. The teacher could utilize the ICT media in delivering the message in the classroom. This proved that the teacher was open minded and flexible to receive the technological changes as the culture in Al Iman boarding school. The implementation of the audio-visual media as alternative media used in English class had two benefits. First, the use of audio-visual media was effective in promoting students' motivation in learning English. Second, according to the teacher, the students seem to be more active in the class. Interactive learning was implemented by the teacher in which he has a good relationship with the students. The atmosphere in the class in conducive because the teacher could manage the class properly. This was because a good relationship between the teacher and the students where they will always meet each other not only in the classroom, but also in the dormitory and pesantren activities

\section{REFERENCES}

[1] S. Dogancay-Aktuna, "Intercultural communication in English language teacher education,” ELT J., vol. 59, no. 2, pp. 99-107, Apr. 2005.

[2] M. S. Zuhriy, "Budaya Pesantren dan Pendidikan Karakter pada Pondok Pesantren Salaf,” Walisongo J. Penelit. Sos. Keagamaan, vol. 19, no. 2, pp. 287-310, 2011.

[3] K. Steenbrink, Pesantren, madrasah, sekolah: pendidikan Islam dalam kurun modern. Jakarta: LP3ES, 1994.

[4] A. Wahid, Menggerakkan Tradisi. Yogyakarta: LKIS, 2001.

[5] A. Haedari, Masa Depan Pesantren Dalam Tantangan Modernitas Dan Tantangan Kompleksitas Global. Jakarta: IRD Press, 2006.

[6] A. Rofik, Pembaruan Pesantren (Respon terhadap Tuntutan Transformasi Global). Jember: STAIN Jember Press, 2012. 
[7] H. D. Brown, Principles of Language Learning and Teaching. New Jersey: Prentice Hall.

[8] W. Littlewood, Foreign and Second Language Learning. Cambridge: Cambridge University Press, 1984.

[9] K. Risager, "The Language Teacher Facing Transnationality The Language Teacher Facing Transnationality," in 1st EUNoM Symphosium, 2010, pp. 1-13.

[10] C. Kramsch, Context and Culture in Language Teaching. New York: Oxford University, 1996.

[11] M. Hammersley, Classroom Ethnography: Empirical and Methodological Essays. Bristol: Open University Press, 1990.

[12] R. C. Bogdan and B. S. K, Qualitative Research for Education: An Introduction to Theory and Methods. Boston: Allyn and Bacon, 2003. 